\title{
Comparative Analysis of the Effect of Immersive English Teaching
}

\author{
https://doi.org/10.3991/ijet.v16i23.27825 \\ Yanan Hao( $\left.{ }^{\bowtie}\right)$, Jiangyong Zhao, Kun Liang \\ Shijiazhuang University of Applied Technology, Shijiazhuang, China \\ 2007010503 esjzpt.edu.cn
}

\begin{abstract}
Immersive teaching has achieved remarkable results in bilingual learning. This teaching method creates an immersive environment for learners to understand and use languages. This paper explores the influence of immersive teaching on the learning performance, interest, and satisfaction of Chinese English learners, and provides several suggestions on how to apply immersive teaching. The results show that immersive teaching improves the listening, speaking, reading, and writing abilities of students. One semester of immersive teaching improved the scores of listening, reading, speaking, and writing by $6.53 \%, 6.85 \%, 5 \%$, and $4.73 \%$, respectively; while two semesters of immersive teaching improved them by $12.46 \%, 16.03 \%, 13.55 \%$, and $9.92 \%$, respectively. Thanks to immersive teaching, the students' interest in English learning soared, and their satisfaction with English learning surpassed 50\%. This research lays a theoretical basis for promoting immersive teaching, and improving students' English learning effect.
\end{abstract}

Keywords-immersive teaching, English learning, teaching effect, learning interest, satisfaction

\section{$1 \quad$ Introduction}

Teaching effect examines the influence of interactive activities of teachers and students in the class on students' learning results [1]. An effective teaching method is the key to ensuring a good effect of classroom teaching $[2,3]$. The classroom English teaching is not only an important place for language learning, but also the most effective way to improve language skills [4]. In China, English learning is carried out mostly in the Chinese environment, so for Chinese English learners, the opportunity and time of immersive learning are far from enough $[5,6]$. At present, the form of English teaching in China is mainly the teacher-centered classroom English teaching, which focuses more on the learning process of the English language [7, 8].

Teaching effect is ultimately reflected in teacher's work performance and student's academic achievement [9]. Current schools generally have very strict criteria for teaching quality evaluation, they take the construction of internal quality system as an important means to optimize the organization structure, and they have set teaching quality monitoring and evaluation teams to assess and feed back the various teaching 
quality factors and teaching process links $[10,11]$. Teaching effect is affected by many factors, as such the combination of basic teaching elements, teaching goals, teaching content, teaching strategy, teacher quality, and teaching environment, etc. $[12,13]$. There is a certain correlation between teaching environment and teaching effect, the combination of basic teaching elements has an impact on teaching efficiency, and the elements of teaching process have a certain impact on teaching effect [14, $15]$.

The immersive teaching method was first proposed by Canadian scholars in the mid-twentieth century. It is a direct and basic teaching method for second language, students are immersed in the "target language" environment, teachers use the target language to teach not only the language course, but also other courses $[16,17]$. In common education, from elementary school, middle school, high school, until college, every student has to spend a lot of time and energy on English learning, however, the effect is not ideal [18]. The immersive teaching method is to immerse learners in the language, use the environment to make them understand and use the language, in such an actual environment, learners can have a good sense of English language and gain use experience, thereby internalizing the language and making it an ability of his/her own [19]. Immersive classroom English teaching is a good teaching method that can save lots of time and effort, it is an education mode rooted in the characteristics of the language [20, 21]. Some scholars experimented on the immersive English teaching in primary schools in China and found that the implementation of immersive teaching has increased the teaching burden of teachers, and adopting semi-immersive teaching in the early stage would achieve better teaching effect. Based on the immersive teaching method, this paper attempts to explore the influence of immersive teaching on the learning performance, interest, and satisfaction of English learners, and provide suggestions on how to apply immersive teaching.

\section{Basic situation and system of immersive English teaching}

\subsection{Basic situation}

The daily life of Chinese English learners is surrounded by the sounds and texts of Chinese language, they lack a natural learning environment of English language, and the traditional English teaching method overemphasizes on using mother tongue to teaching English. The immersive-style teaching takes both the students' learning interest and motivation into account, it provides the knowledge of disciplines required by students and satisfies their learning needs, thus it can greatly stimulate students' interest in learning [22]. Figure 1 shows the classification of immersive classroom English teaching. There are various immersion modes, including full immersion, partial immersion, intermittent immersion, later-stage immersion, double immersion, structurally-limited immersion, and two-way bilingual immersion, etc. Compared with traditional classroom teaching, immersive teaching has the characteristics of coordinated, creative and specific; it pays more attention to the close cooperation between body and mind, and its classroom teaching mode emphasizes the use of both 
mind and body $[23,24]$. The tasks of immersive teaching can arouse students' desire to learn $[25,26]$.

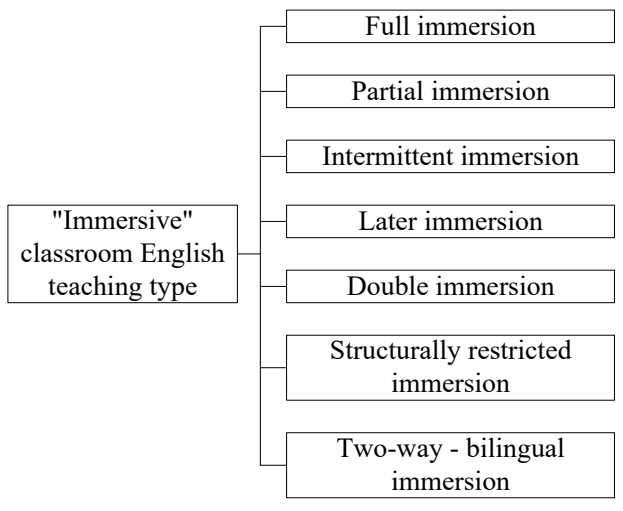

Fig. 1. Classification of immersive classroom English teaching

Figure 2 shows the characteristics of the teaching path of English learning. According to the relationship among practice, communication, and autonomy, the teaching path characteristics of English teaching can be divided into 8 types, among which, the high practice-low communication-low autonomy pays more attention to the guidance of teachers and the personal experience of students; the low practice-high communication-low autonomy pays more attention to the interactive learning among students; the low practice-high communication-high autonomy pays more attention to the discussion between teachers and students.

\begin{tabular}{|c|c|}
\hline Characteristics of teaching path & Case \\
\hline $\begin{array}{l}\text { Low practice, low autonomy, low } \\
\text { communication }\end{array}$ & Teachers always teach \\
\hline $\begin{array}{l}\text { High practice, low autonomy, low } \\
\text { communication }\end{array}$ & $\begin{array}{l}\text { Teachers guide, students } \\
\text { personally experience }\end{array}$ \\
\hline $\begin{array}{l}\text { Low practice, high autonomy, low } \\
\text { communication }\end{array}$ & $\begin{array}{c}\text { Interactive learning among } \\
\text { students }\end{array}$ \\
\hline $\begin{array}{l}\text { Low practice, low autonomy, high } \\
\text { communication }\end{array}$ & $\begin{array}{l}\text { The teacher arranges, the student } \\
\text { prepares independently }\end{array}$ \\
\hline $\begin{array}{l}\text { High practice, high autonomy, } \\
\text { low communication }\end{array}$ & $\begin{array}{l}\text { Teacher control, implement } \\
\text { interactive experience }\end{array}$ \\
\hline $\begin{array}{l}\text { Low practice, high autonomy, } \\
\text { high communication }\end{array}$ & $\begin{array}{l}\text { Discussion between teachers and } \\
\text { students }\end{array}$ \\
\hline $\begin{array}{l}\text { High practice, low autonomy, } \\
\text { high communication }\end{array}$ & $\begin{array}{l}\text { Independent and experiential } \\
\text { teaching }\end{array}$ \\
\hline $\begin{array}{l}\text { High practice, high autonomy, } \\
\text { high communication }\end{array}$ & $\begin{array}{l}\text { Teachers and students work } \\
\text { together to solve problems }\end{array}$ \\
\hline
\end{tabular}

Fig. 2. Characteristics of teaching path in English learning 


\subsection{The system of immersive English teaching}

When establishing a long-term support mechanism for the implementation of developmental teaching effect evaluation, the test scores of students shouldn't be taken as the only indicator to evaluate the teachers [27, 28]. Figure 3 summarizes deficiencies in current teaching evaluation, including: emphasizing on management while neglecting incentives, and teaching effect evaluation has become a pure management tool of schools; the evaluation of teaching conditions is insufficient, schools often evaluate the teaching of teachers and the learning of students, while there's few evaluations on the positioning of disciplines, the school faculty, or the teaching conditions of disciplines; the evaluation of teaching organization and management is insufficient, schools often neglect the evaluation of teaching organization and management; the evaluation of the quality of practical teaching is insufficient, most schools tend to focus on theoretical teaching, while neglecting the evaluation of practical teaching; the evaluation of student abilities is insufficient, and few attention has been paid to their evaluation opinions.

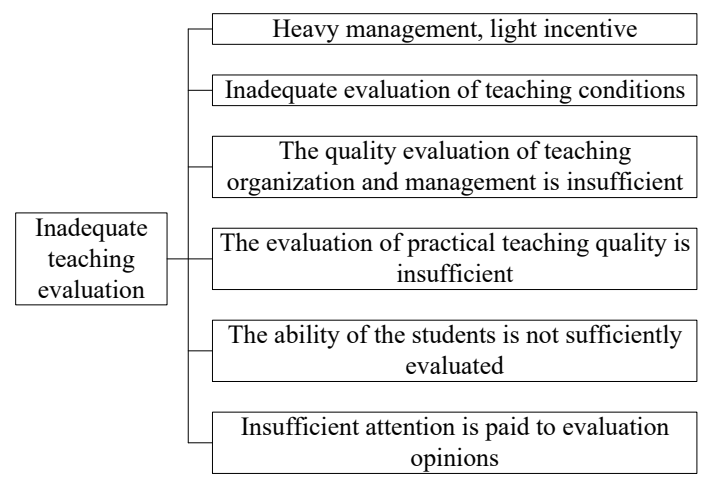

Fig. 3. Deficiencies in current teaching evaluation

The practice-communication-autonomy theoretical model points out the direction for students to conduct immersive learning, and it also indicates the possible ways for students to implement the activities of immersive classroom English teaching [29, 30]. Teachers let students exert their abilities in the immersive English teaching environment, and develop and enhance their actual language application abilities through set scenarios, collaborations, and conversations, etc. [31, 32]. Figure 4 shows the system of immersive classroom English teaching. In an immersive English class, the teaching tasks simulate scenarios of listening, speaking, reading, writing and translation; the classroom teaching focuses on the cultivation of students' abilities in listening, speaking, reading, writing and translation, and the realization of the teaching effect of practice-communication-autonomy. The correct implementation of immersive teaching can improve students' knowledge learning effect, help them develop a good learning attitude, enable them to consolidate their academic achievements; by independently exploring the teaching materials, students' autonomous learning ability could be strengthened. 


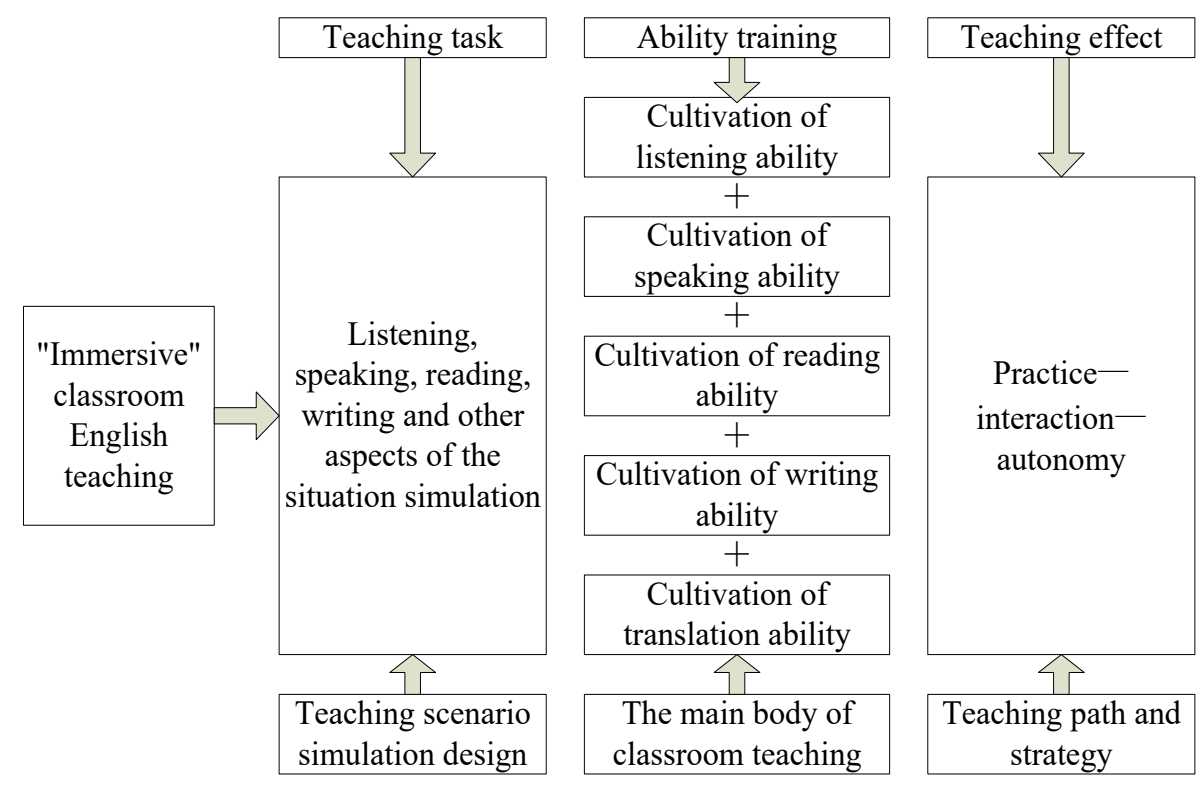

Fig. 4. The system of immersive classroom English teaching

\section{Effect of immersive English teaching}

\subsection{Research methods and objects}

Studies on the effect of immersive English teaching mainly include two aspects: impact of immersive teaching on the exam scores of students, and the impact of immersive teaching on students' learning interest and satisfaction. Research objects of this paper are students in two classes of the middle/high school affiliated to Nanchang University. The two classes were taught by a same English teacher but using two different teaching methods, one class adopted the traditional English teaching, while the other adopted the immersive English teaching, the test period had lasted for one year (two semesters), by the end of each semester, the English learning performance of the students was examined to see if there're changes after adopting the immersive English teaching method. Table 1 gives some information of the research objects and teaching methods. To ensure good accuracy of the test data, both examination and questionnaire survey were taken as research methods, question types of the English exam included word translation, phrase translation, reading comprehension, listening, writing, and oral description.

Table 1. Research objects and teaching methods

\begin{tabular}{|l|c|c|}
\hline \multicolumn{1}{|c|}{ Research object } & Number & Teaching method \\
\hline Control group & 120 & Traditional English teaching \\
\hline Test group & 121 & Immersive English teaching \\
\hline
\end{tabular}




\subsection{Results and discussion}

Immersive teaching has the characteristics of coordinated, creative and specific $[33,34]$. Our study took the changes in the English exam scores of the students after adopting immersive teaching for one semester and two semesters as the basis. Figure 5 and Figure 6 respectively give the average English scores of students after adopting immersive English teaching for one semester and for two semesters. According the figures, it can be clearly seen that, after adopting immersive English teaching, students' listening, speaking, reading, and writing abilities had all improved to vary degrees. After adopting immersive teaching for one semester and two semesters, the English listening scores of students had improved by $6.53 \%$ and $12.46 \%$, the English reading scores had improved by $6.85 \%$ and $16.03 \%$, the English speaking scores had improved by $5 \%$ and $13.5 \%$, and the English writing scores had improved by $4.73 \%$ and $9.92 \%$.

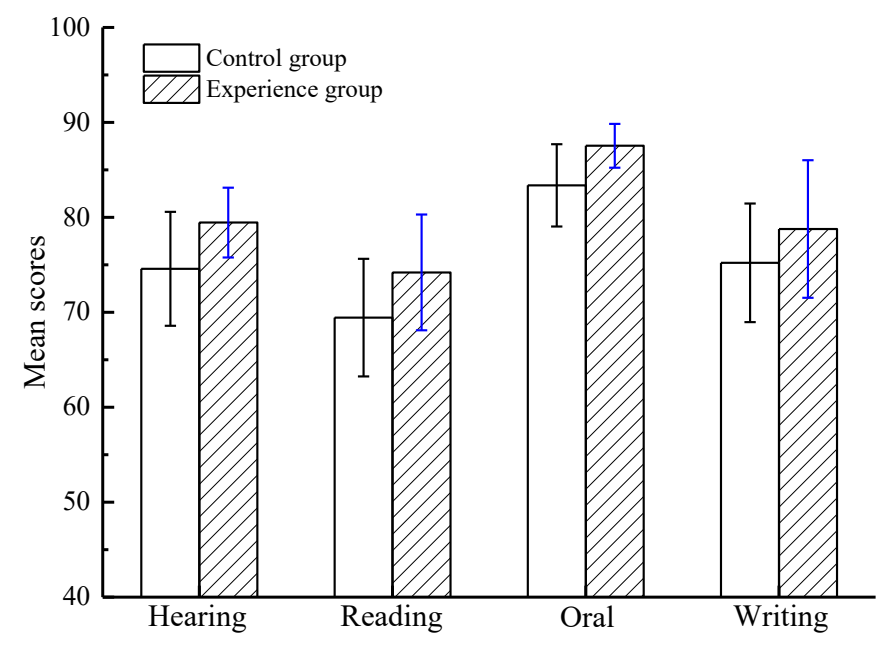

Fig. 5. Average English scores of students after adopting immersive teaching for one semester

Moreover, students' English learning interest and satisfaction were investigated through a questionnaire survey. Figure 7 shows the scores of English learning interest of students in the control group and in the test group. Taking the English vocabulary learning as an example, it's obvious that the overall learning interest, the individual vocabulary learning interest, and the situational vocabulary learning interest of the test group were all higher than those of the control group. Figure 8 shows students' self-evaluation of their learning effect. After adopting immersive teaching, students' satisfaction degrees of their listening, speaking, grammar, reading, and cross-cultural knowledge learning abilities had all exceeded $50 \%$. 


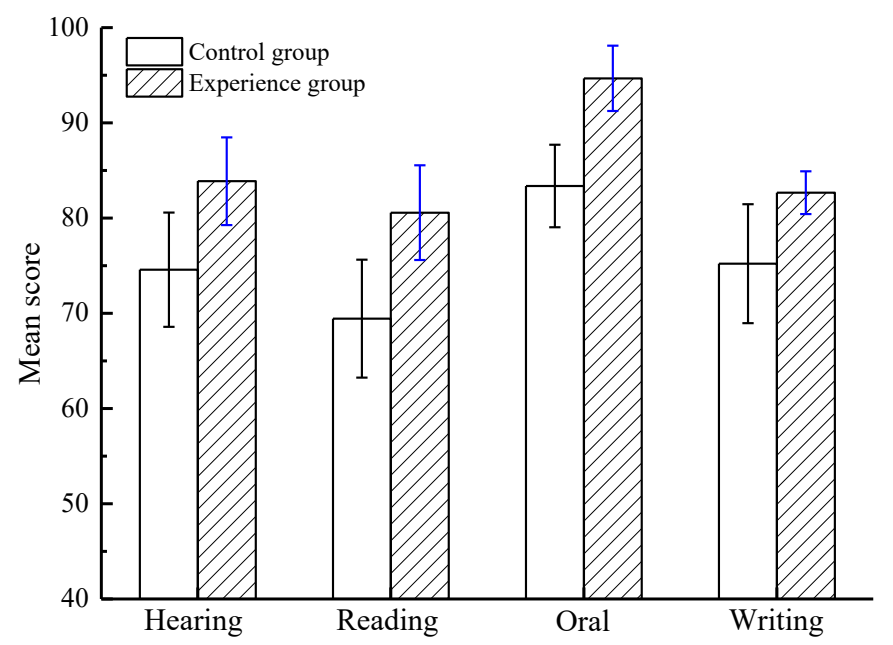

Fig. 6. Average English scores of students after adopting immersive teaching for two semesters

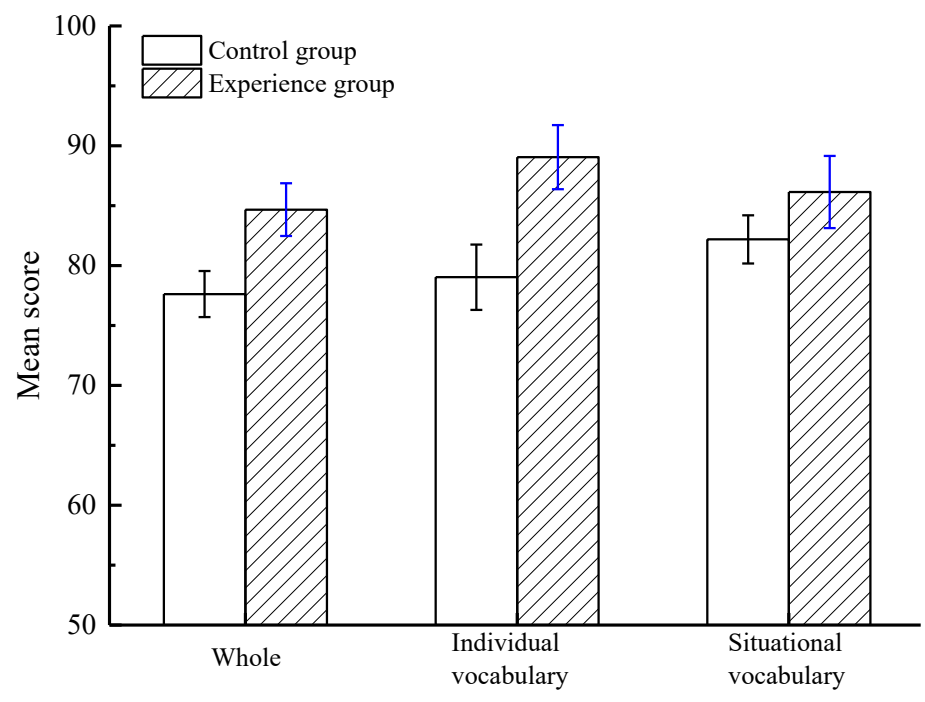

Fig. 7. Students' English learning interest 


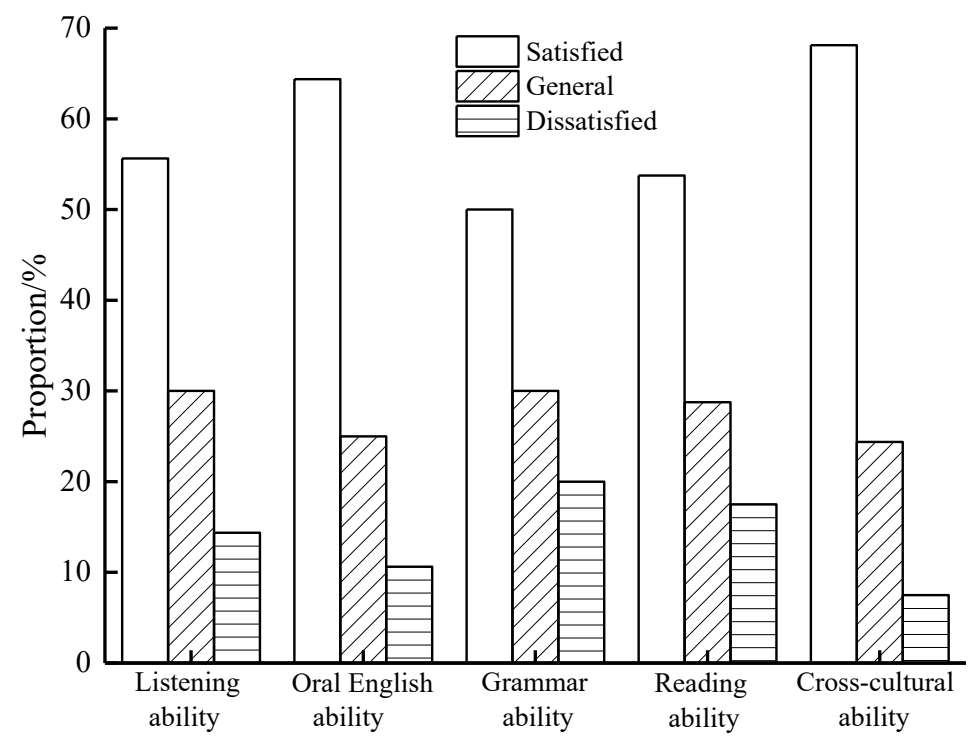

Fig. 8. Students' self-evaluation of their learning effect

\section{$4 \quad$ Evaluation of immersive teaching}

\subsection{Students' evaluation of immersive teaching}

Combining with the characteristics of immersive teaching, after surveying students' learning performance, learning interest, and satisfaction, we had discovered a few advantages and disadvantages of the immersive teaching. Figure 9 shows the evaluation content of the effect of immersive teaching. Students were concentrated and interested; they can well grasp and digest the theoretical knowledge taught in the classroom; their abilities to analyze and solve problems had been trained; their ideological quality and practical ability had been improved; the class can provide guidance and effectively improve experience. Figure 10 summarizes the shortcomings of immersive English teaching. There isn't a connection between the English subject and other subjects; English learning has a certain order, however, sometimes the course content is not arranged according to the sequence of language acquisition; the English teaching content is not reasonably arranged, the classroom teaching is not scientifically organized, and it is difficult for students to consolidate the acquired knowledge points under current teaching schedule; student participation in classroom activities is very low; many teachers have an excellent educational background but lack of professional English teaching training, therefore, whether they are truly suitable for teaching students is questionable, and the corresponding training is required; facilities for constructing teaching scenarios are outdated; the class hour arrangement of English teaching is unreasonable. 


\begin{tabular}{|c|}
\hline $\begin{array}{c}\text { The students are focused and interested } \\
\text { Teaching } \\
\text { efficiency }\end{array}$ \\
$\begin{array}{c}\text { Analytical and problem solving skills are } \\
\text { knoweloped } \\
\text { knowedge in class }\end{array}$ \\
\hline $\begin{array}{c}\text { Ideological quality and practical ability have } \\
\text { been improved }\end{array}$ \\
\hline $\begin{array}{c}\text { Classes are instructive and can effectively } \\
\text { improve the experience }\end{array}$ \\
\hline
\end{tabular}

Fig. 9. Evaluation content of the effect of immersive teaching

\begin{tabular}{|c|}
\hline $\begin{array}{c}\text { The deficiency of } \\
\text { immersion teaching } \\
\text { in English teaching }\end{array}$ \\
and the other subjects
\end{tabular}

Fig. 10.Shortcomings of immersive English teaching

\subsection{Suggestions for immersive English teaching}

Through research, it is found that immersive teaching can significantly improve students' learning performance, interest, and satisfaction, and the effect of immersive English teaching is obvious. Targeting at the shortcomings of immersive teaching summarized in above paragraph, this section proposes the following suggestions, as shown in Figure 11, first, create connections between the English subject and other subjects, English teachers should flexibly adjust the teaching content according to the syllabus, and pay attention to the relevance between subjects when formulating the syllabus. Second, improve the teaching methods of English grammar and vocabulary, optimize the content of immersive teaching, enhance interaction and discussion between students and teachers, and increase the fun of English learning. Third, help students build self-confidence and provide them with materials for setting up teaching scenarios. Fourth, strengthen the teaching training of teachers, and improve the professionalism of qualified English teachers; professional training programs should be 
held for course teachers, and each teacher should share his/her experience of immersive teaching. Fifth, upgrade teaching facilities and improve teaching efficiency. Sixth, well arrange the class hours of immersive teaching, and increase free activity courses.

The full immersion mode is suitable for the teaching of English listening, it enables students to find topics based on their own situations. The intermittent immersion mode is suitable for the teaching of English reading, it enables students to understand the reading materials, accurately extract the viewpoints of the materials, infer the corresponding vocabulary, and process them based on the scenario. The two-way bilingual immersion mode is suitable for the teaching of English writing, it enables students to use English to conceive and write articles; writing ability mainly comes from daily life and reading training, it enables students to express their opinions, conform to English writing habits, and make complete sentence structure. The one-way bilingual immersion mode is suitable for the teaching of English translation, it enables students to use another language to express the content of a language completely and accurately.

\begin{tabular}{|l|c|}
\hline $\begin{array}{c}\text { Suggestions for English } \\
\text { teaching by immersing } \\
\text { teaching methods }\end{array}$ & $\begin{array}{c}\text { Improve the relevance of English to the } \\
\text { syllabus of other subjects }\end{array}$ \\
\hline $\begin{array}{c}\text { Improve English grammar, vocabulary and } \\
\text { other teaching methods, optimize the } \\
\text { immersion teaching content }\end{array}$ \\
\hline $\begin{array}{c}\text { Help students build confidence and provide } \\
\text { materials for students to set up scenes }\end{array}$ \\
\hline $\begin{array}{c}\text { Strengthen the teaching training of teachers } \\
\text { and improve the professionalism of qualified } \\
\text { English teachers }\end{array}$ \\
\hline $\begin{array}{c}\text { Improve teaching facilities and improve } \\
\text { teaching efficiency }\end{array}$ \\
\hline $\begin{array}{c}\text { Reasonable arrangement of immersion } \\
\text { teaching hours, increase free activity courses }\end{array}$ \\
\hline
\end{tabular}

Fig. 11.Suggestions for immersive teaching

\section{Conclusion}

This paper explored the impact of immersive teaching on the English learning performance, interest, and satisfaction of students, summarized the shortcomings of current immersive English teaching, and proposed a few suggestions targeting at these shortcomings, the specific conclusions are:

1. Correctly applying immersive teaching can improve students' knowledge learning effect, help them develop a good learning attitude, enable them to consolidate their 
academic achievements; by independently exploring the teaching materials, students' autonomous learning ability could be strengthened.

2. After applying immersive teaching, students' listening, speaking, reading, and writing abilities had improved by 5\%-16\% after two semesters of immersive English teaching.

3. After applying immersive teaching, students' satisfaction degrees of their listening, speaking, grammar, reading, and cross-cultural knowledge learning abilities had all exceeded $50 \%$.

\section{References}

[1] Qadha, A.M.H., Alward, M.A. (2020). The effect of using videos in teaching and learning English present progressive tense. Interactive Technology and Smart Education, 37(1): 7493. https://doi.org/10.1108/itse-08-2019-0045

[2] Hua, S.Y., Ren, Z.W. (2020). "Online + Offline" Course Teaching Based on Case Teaching Method: A Case Study of Entrepreneurship Education Course, International Journal of Emerging Technologies in Learning, 15(10), 69-85. https://doi.org/10.3991/ijet.v15i10 .13999

[3] Wang, Y. (2020). Application of Virtual Reality Technique in the Construction of Modular Teaching Resources, International Journal of Emerging Technologies in Learning, 15(10), 126-139. https://doi.org/10.3991/ijet.v15i10.14129

[4] Farrokh, P. (2019). The effectiveness of Hymes' ethnography of communication model in teaching English learners reading comprehension. Learning and Teaching in Higher Education: Gulf Perspectives, 16(1): 58-66. https://doi.org/10.18538/lthe.v16.n1.315

[5] Chen, J. (2020). Strategies for improving the effectiveness of English translation teaching in higher vocational colleges based on data mining. Journal of Physics Conference Series, 1693: 012021. https://doi.org/10.1088/1742-6596/1693/1/012021

[6] Qian, J., Wang, Z. (2020). A comparative study on the effectiveness of online automatic scoring of English writing in JUKU correction network and mosoteach app under blended teaching mode. Journal of Physics Conference Series, 1533(4): 042082. https://doi.org/ $10.1088 / 1742-6596 / 1533 / 4 / 042082$

[7] He, C. (2013). Effect of network-assisted language teaching model on undergraduate English skills. English Language Teaching, 6(6): 29-37. https://doi.org/10.5539/elt. v6n6p29

[8] Zhao, Y.X., Ren, W., Li, Z. (2020). Prediction of English scores of college students based on multi-source data fusion and social behavior analysis. Revue d'Intelligence Artificielle, 34(4): 465-470. https://doi.org/10.18280/ria.340411

[9] Wilkinson, S.D., Penney, D. (2014). The effects of setting on classroom teaching and student learning in mainstream mathematics, English and science lessons: a critical review of the literature in England. Educational Review, 66(4): 411-427. https://doi.org/ 10.1080/00131911.2013.787971

[10] Cloud, N., Coordinator, J., Teacher, E. (2012). Learner-centered teaching: the core of effective practices for adolescent English language learners. Tesol Journal, 2(2): 132-155. https://doi.org/10.5054/tj.2011.250377

[11] Ren, Y. (2011). A study of the washback effects of the college English test (band 4) on teaching and learning English at tertiary level in China. International Journal of Pedagogies and Learning, 6(3): 243-259. https://doi.org/10.5172/ijpl.2011.6.3.243

[12] Dunne, M. (2014). Addressing the Cinderella area: using masters level study to support secondary English trainee teachers in developing effective teaching and assessment of 
speaking and listening. English in Education, 48(1): 93-107. https://doi.org/10.1111 leie. 12033

[13] Urmston, A.W. (2003). Learning to teach English in Hong Kong: Effects of the changeover in sovereignty. Language Teaching Research, 5(2): 178-179. https://doi.org/ $10.1177 / 136216880100500205$

[14] K1liçkaya, F. (2009). The effect of a computer-assisted language learning course on preservice English teachers' practice teaching. Educational Studies, 35(4): 437-448. https://doi.org/10.1080/03055690902876545

[15] Skinner, B., Abbott, L. (2013). An exploration of differences in cultural values in teacher education pedagogy: Chinese English language teacher trainees' perceptions of effective teaching practice review. Teacher Development, 17(2): 228-245. https://doi.org/10. 1080/13664530.2012.753937

[16] Nation, K., Angell, P., Castles, A. (2007). Orthographic learning via self-teaching in children learning to read English: effects of exposure, durability, and context. Journal of Experimental Child Psychology, 96(1): 71-84. https://doi.org/10.1016/j.jecp.2006.06.004

[17] Gömleksi z, M.N. (2007). Effectiveness of cooperative learning (jigsaw ii) method in teaching English as a foreign language to engineering students (case of Firat University, Turkey). European Journal of Engineering Education, 32(5): 613-625. https://doi.org/ 10.1080/03043790701433343

[18] Olson, K., Jimenez-Silva, M. (2008). The campfire effect: a preliminary analysis of preservice teachers' beliefs about teaching English language learners after state-mandated endorsement courses. Journal of Research in Childhood Education, 22(3): 246-260. https://doi.org/10.1080/02568540809594625

[19] Solari, E.J., Gerber, M.M. (2008). Early comprehension instruction for Spanish-speaking English language learners: teaching text-level reading skills while maintaining effects on word-level skills. Learning Disabilities Research and Practice, 23(4): 155-168. https://doi.org/10.1111/j.1540-5826.2008.00273.x

[20] Klingenberg, S., Jrgensen, M., Dandanell, G., Skriver, K., Mottelson, A., Makransky, G. (2020). Investigating the effect of teaching as a generative learning strategy when learning through desktop and immersive VR: A media and methods experiment. British Journal of Educational Technology, 51(6): 2115-2138. https://doi.org/10.1111/bjet.13029

[21] Tan, Q., Shao, X. (2021). Construction of college English teaching resource database under the background of big data. Journal of Physics Conference Series, 1744(3): 032004. https://doi.org/10.1088/1742-6596/1744/3/032004

[22] Kim, H., Rah, Y. (2021). Applying constructionist approaches to teaching English argument structure constructions to EFL learners. TESOL Quarterly, 55(2): 568-592. https://doi.org/10.1002/tesq.3002

[23] Wen, J., Fu, F. (2021). English teaching courses for students majoring in occupational health in higher vocational education based on virtual reality. Journal of Physics: Conference Series, 1881(4): 042020. https://doi.org/10.1088/1742-6596/1881/4/042020

[24] Yang, Y. (2018). Study on the construction of multimodal interactive oral English teaching model. Open Journal of Modern Linguistics, 8(4): 137-142. https://doi.org/10. 4236/ojml.2018.84014

[25] Sun, Z. (2015). A tentative study on the task-based teaching of writing to English majors in Chinese settings. English Language Teaching, 8(3): 71-79. https://doi.org/10.5539/ elt.v8n3p71

[26] Lestari, S., Setiyawan, R. (2020). Technology era, global English, CLIL: influence and its impact on English teaching for young learners in Indonesia. IOP Conference Series Earth and Environmental Science, 469: 012094. https://doi.org/10.1088/1755-1315/469/ $\underline{1 / 012094}$ 
[27] Zhong, Y. (2020). Analysis of higher vocational English teaching behavior integrating network information teaching. Journal of Physics Conference Series, 1648(3): 032150. https://doi.org/10.1088/1742-6596/1648/3/032150

[28] Tseng, P.H., Pilcher, N., Richards, K. (2020). Measuring the effectiveness of English medium instruction shipping courses. Maritime Business Review, 5(4): 351-371. https://doi.org/10.1108/MABR-10-2019-0042

[29] Luo, W.H. (2014). An inquiry into the nest program in relation to English teaching and learning in Taiwanese primary schools. English Language Teaching, 7(1): 149-158. https://doi.org/10.5539/elt.v7n1p149

[30] Mori, S., Tanabe, Y. (2014). Influence of instructor personality on student evaluation of teaching: a comparison between English majors and non-English majors. English Language Teaching, 8(1): 1-10. https://doi.org/10.5539/elt.v8n1p1

[31] Chen, J. (2021). A creative research on interactive English teaching based on computer aid. Journal of Physics Conference Series, 1802(3): 032140. https://doi.org/10.1088/17426596/1802/3/032140

[32] Du, J. (2021). English applied ability teaching reform of mechanical design and manufacturing in ESP teaching mode. Journal of Physics Conference Series, 1820(1): 012017. https://doi.org/10.1088/1742-6596/1820/1/012017

[33] Huang, M.R. (2020). Reform of higher vocational English teaching based on mobile Moodle platform. Journal of Physics Conference Series, 1533(2): 022036. https://doi.org/ $\underline{10.1088 / 1742-6596 / 1533 / 2 / 022036}$

[34] Cai, S.G., Ouahsine, A., Favier, J., Hoarau, Y. (2017). Moving immersed boundary method. International Journal for Numerical Methods in Fluids, 85(5): 288-323. https://doi.org/10.1002/fld.4382

\section{$7 \quad$ Authors}

Yanan Hao is an associate professor working on English teaching in the School of Shijiazhuang University of Applied Technology, China. She graduated from the University of Waikato in New Zealand. She has been working in English teaching after graduation. Her research interests include Teaching Methods and Second Language Acquisition. She has conducted and participated in 5 research projects, and published 7 papers.

Jiangyong Zhao is an associate professor working in the Department of Public Foreign Language in Shijiazhuang University of Applied Technology, China. His research interests include English competitions and teaching methodology. Three papers are published and 3 text books are published (email: 2003100492@sjzpt .edu.cn).

Kun Liang is a lecturer and working on Department of Public Foreign Languages of Shi jiazhuang University of Applied Technology, Hebei, China. She graduated from Hebei Normal University and the research interests is the teaching method of higher vocational. Since she got the lecturer, she has published more than eight papers and four books (email: 2010110600@sjzpt.edu.cn).

Article submitted 2021-09-24. Resubmitted 2021-10-27. Final acceptance 2021-10-30. Final version published as submitted by the authors. 